\title{
AN APPROACH TO OPTIMIZE COSTS DURING ULTRA-LOW HYDRODESULFURIZATION OF A BLEND CONSISTING OF DIFFERENT OIL STREAMS
}

\author{
J. I. S. da Silva ${ }^{1 *}$ and A. R. Secchi ${ }^{1}$ \\ ${ }^{1}$ Chemical Engineering Program, COPPE, Universidade Federal do Rio de Janeiro. Av. Horácio Macedo 2030, \\ Centro de Tecnologia, Bloco G, Sala G-115, CEP: 21941-914, Rio de Janeiro - RJ, Brasil.
}

(Submitted: July 11, 2017 ; Revised: December 30, 2017 ; Accepted: December 31, 2017)

\begin{abstract}
The presence of contaminants in diesel oil is severely controlled. These components affect the diesel properties, causing impacts on the emissions of pollutants and compromising its commercialization. The Brazilian legislation imposes the use of diesel S10. In this work, a hydrotreatment unit fed with multiple diesel streams was optimized using a phenomenological mathematical model. A three-phase model of a tricked-bed reactor was considered. The optimization of the process was performed with the interior point method considering the hydrodesulfurization reaction of diesel. It was proposed to minimize the operating cost, keeping the amount of sulfur in the final product below the maximum allowed value. The EMSO process simulator was used to model, simulate and optimize the hydrotreatment process. It was observed that the optimization strategy drove the contaminant content into the diesel S10 specification range, as well as reducing the process operating cost by increasing the feed temperature and hydrogen flowrate and adjusting the feed composition blend of the available diesel streams.

Keywords: Hydrotreatment; Diesel S10; Optimization.
\end{abstract}

\section{INTRODUCTION}

The literature is very vast when it comes to the hydrotreatment (HDT) process of petroleum fractions, with many researches addressing the search for the improvement of this process, both in pilot and commercial scale. The diesel hydrotreating process usually occurs in a three-phase heterogeneous reactor, and much effort has been made to improve this operation. But challenges still exist to optimize the HDT process. Trickle-bed reactors (TBR) are widely used in petroleum refineries for hydrotreating processes and for hydrocracking processes (Bhaskar et al., 2004). With the HDT process, impurities such as heteroatoms (sulfur, nitrogen and oxygen), polynuclear aromatics and some metallic compounds, which compromise the diesel quality, can be reduced and even eliminated, meeting the product specifications (Li et al., 2013).

Catalytic hydrotreating is an extremely relevant operation in the petroleum industry, as this process improves a wide variety of products, from direct distillation naphtha to vacuum distillation residues or even in operations with heavy crude oils, gasoil and diesel oil (Alvarez and Ancheyta, 2008a; Ancheyta et al., 2005).

The content of contaminants influences the quality of the diesel oil, generating impacts on its commercialization ( $\mathrm{Li}$ et al., 2013). The amount of these contaminants present in the diesel such as sulfur and nitrogen must comply with the regulations contained in specific legislation of the fuel sector. In recent years, environmental issues have become an

\footnotetext{
*E-mail: josesilva@peq.coppe.ufrj.br; arge@peq.coppe.ufrj.br
} 
important consideration in discussions around the world, raising the cravings for strong pollution control legislation, especially when it comes to emissions from the use of petroleum products (Ferreira et al., 2013).

The current legislation in Brazil imposes Diesel S10, which contains a maximum of $10 \mathrm{ppm}$ of sulfur in its composition. The production of this fuel requires the intensive use of hydrotreatment units (HDT), with the need for catalysts of high activity and severe operating conditions (Pacheco et al., 2011; Ferreira et al., 2013). One of the most difficult ways to achieve success in diesel hydrotreating is to operate the plant observing different conditions such as product prices and feed that changes constantly (Adetola and Guay, 2010; Jarullah et al., 2011a).

Hydrotreating is a process in which the feed stream, practically any fraction of the oil, reacts with hydrogen at high pressures and temperatures in the presence of a heterogeneous catalyst (Korsten and Hoffmann, 1996; Murali et al., 2007). According to Aye and Zhang (2005) and Ferreira et al. (2013), kinetic models are fundamental for a good performance of the HDT simulation, and the optimization of the hydrotreatment process can benefit from reliable kinetic models of the hydrodesulfurization reactions, among others.

The HDT process, especially deep hydrodesulfurization (HDS) of diesel continues to attract research interest due to environmental regulations which limit sulfur content in several countries (Ali, 2014). Aiming to meet environmental regulations and to reduce diesel engine's harmful emissions, many countries are attempting to produce diesel fuel with ultra low levels of sulfur content (ultra low sulfur diesel, ULSD). Research on the production of ULSD has gained great interest around the world, focusing on deep desulfurization of diesel and on finding cost-effective methodology for ultra low sulfur diesel production. In this way, Stanislaus et al. (2010) discussed advancement in ULSD production from scientific and applied points of view. The authors showed evolution in deep HDS catalysts and advancement in the deep HDS process technologies.

In the literature, few studies were found addressing the optimization of the HDT process of diesel, as well as for the control of the process. Ahmad et al. (2011) studied process integration in the design of a HDT unit, using the simulated annealing algorithm to minimize capital and operating costs. Jarullah et al. (2011a) obtained experimental data for the HDT process in a pilot plant and set up an optimization problem to minimize the total annual cost of the process in the pilot plant, having as optimization variables the inlet and outlet temperatures, subject to system limitations such as the amount of heat involved in the process and the pressure of the system. The authors showed that, with optimization, costs were reduced by approximately 55\%. Shokri et al. (2010), aiming to determine the optimal conditions of the hydrodesulfurization process of diesel oil, applied RTO (Real Time Optimization) methodologies in a pilot plant, considering as optimization variables: temperature, pressure, liquid spatial velocity and the amount of sulfur in the product. The authors stated that, initially, the increase in pressure causes the decrease of the amount of sulfur in the product; however, continuing the increase of pressure, this quantity increases. Increasing the feed flowrate and system pressure simultaneously, with constant temperature, the amount of sulfur in the product increases. Zhang et al. (2010) optimized simultaneously materials and energy for a diesel HDT unit aiming to minimize the total costs. The authors showed that, when the material and energy are simultaneously considered, the results of the optimization are more profitable than those obtained from methods that individually optimize the material or energy. Ani et al. (2015) addressed the problem of diesel HDT, considering the reactions of HDS, HDN and HDA. The authors applied the multiobjective optimization based on a genetic algorithm, seeking the best operating conditions of the TBR. The optimization objectives were to minimize the concentration of sulfur and aromatic compounds in the product, with constraints on the TBR feed temperature and reactor pressure. Residence time of the liquid phase and $\mathrm{H}_{2}$ /oil ratio in the process feed were used as optimization variables. The authors concluded that a very high temperature in the feed stream of hydrogen in the process is not recommended for economic reasons, as well as the fact that this high temperature favors catalyst deactivation, since it accelerates the formation of coke.

In this work, a hydrotreatment unit fed with multiple diesel streams was optimized, using a threephase model for the tricked-bed reactor, considering the HDS process, with the objective to minimize the operating cost, keeping the sulfur concentration in the product below the maximum allowed value by the legislation.

In the next section, the reactor mathematical model and the formulated optimization problem are presented. Then the results are discussed and the main conclusions are stated.

\section{PROBLEM FORMULATION}

A multiple feed diesel HDT process was considered in this work, in which a mathematical model of a trickle-bed reactor was implemented in the EMSO (Environment for Modeling, Simulation and Optimization) process simulator. EMSO is an equation-oriented process simulator with a graphical 
interface for modeling complex dynamic or steadystate processes (Soares and Secchi, 2003). The ALSOC Project (a Portuguese acronym for Free Environment for Simulation, Optimization and Control of Processes) develops, maintains and distributes this objectoriented software. For academic purposes, EMSO is a free software available at $<$ http://www.enq.ufrgs.br/ trac/alsoc $>$.

Fig. 1 shows a scheme of the process that occurs in the presence of a catalytic bed, and the feeds (in which vacuum gas oil, VGO, was considered) are inserted on top of the TBR, which characterize cocurrent operation. Three types of oil (oil A, oil B and oil C) are available to feed the reactor, which can be blended to adjust the feed composition. These feeds are saturated with hydrogen and heated before entering the catalytic bed. At the bottom of the reactor, the treated oil is obtained in the liquid phase, and the removed sulfur leaves the reactor in the gas phase. It was considered that the main difference in the oils $\mathrm{A}, \mathrm{B}$ and $\mathrm{C}$ is the concentration of organic sulfur compounds.

The following assumptions were taken into account to model the HDT reactor:

$>$ Three-phase system: gas, liquid and solid phases;

$>$ Two interfaces (gas-liquid and liquid-solid) through which mass transfer occurs;

$>$ Cocurrent operation with hydrogen saturated feed;

The reactions occur on the surface of the catalyst (in the solid phase);

$>$ Stationary process model;

> One-dimensional mathematical model;

$>$ There are no radial gradients of concentration and temperature;

$>$ The velocities of the liquid and gaseous phases are constant along the reactor;

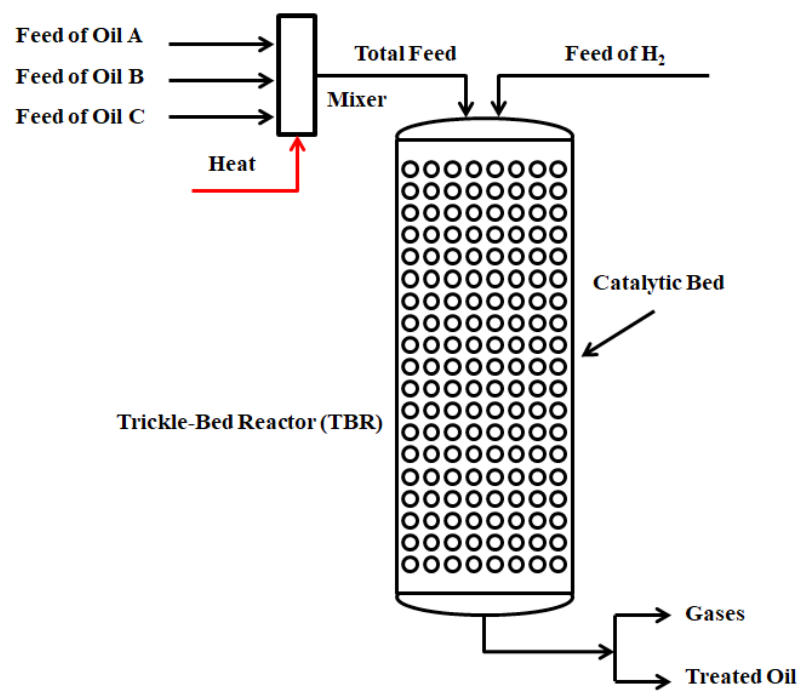

Figure 1. Schematic diagram of the TBR, representing the cocurrent operation of the diesel HDT process.
$>$ Constant operating pressure;

$>$ Pilot scale operation.

Model parameters and mathematical correlations were taken from Korsten and Hoffmann (1996), Mederos and Ancheyta (2007), Jiménez et al. (2007), Liu et al. (2008), Alvarez and Ancheyta (2008a), Alvarez and Ancheyta (2008b) and Mederos et al. (2012), and are sumarized in Appendix. The input data and the operating conditions prior to the optimization are presented in Table 1. The costs of the oils were based on the current market values (ANP, 2017). The API grade of the oils was considered equal to 22 and the molecular weight equal to $441.9 \mathrm{~kg} / \mathrm{kmol}$ (Mederos and Ancheyta, 2007).

Table 1. Information about the system studied.

\begin{tabular}{lc}
\hline \multicolumn{1}{c}{ System Informations } & Values \\
\hline Organic sulfur concentration & 400 (oil A) \\
$(\mathrm{ppm})$ & 300 (oil B) \\
& 200 (oil C) \\
& 0.03 (oil A) \\
Feed $\left(\mathrm{cm}^{3} / \mathrm{s}\right)$ & Mass balance \\
& 0.02 (oil C) \\
TMABP - Average boiling & $0.1(\mathrm{TBR}$ inlet) \\
temperature $\left({ }^{\circ} \mathrm{C}\right)$ & 476 \\
Surface gas velocity $(\mathrm{cm} / \mathrm{s})$ & 0.28 \\
Length of the TBR $(\mathrm{cm})$ & 35 \\
Equivalent particle diameter $(\mathrm{cm})$ & $2.54 \times 10^{-1}(\mathrm{catalyst}$ \\
Operational pressure $(\mathrm{MPa})$ & $\left.\mathrm{CoMo} / \mathrm{Al} \mathrm{O}_{3}\right)$ \\
Liquid Hourly Space Velocity, & 5.3 \\
LHSV, $\left(\mathrm{h}^{-1}\right)$ & 1 \\
& $1.3 \times 10^{-3}$ (oil A) \\
Costs $\left(\mathrm{US} \$ / \mathrm{cm}^{3}\right)$ & $1.4 \times 10^{-3}$ (oil B) \\
& $1.5 \times 10^{-3}$ (oil C) \\
Costs of heat in the mixer & $2.0 \times 10^{-3}$ (hydrogen) \\
(US $\$ / \mathrm{kJ})$ & 3.0 \\
\hline
\end{tabular}

The hydrocarbon concentrations of the oils A, B and C were kept constant equal to $4.93\left(\mathrm{~cm}^{3} \mathrm{~mol}^{-1}\right), 3.85\left(\mathrm{~cm}^{3}\right.$ $\left.\mathrm{mol}^{-1}\right)$ and $2.89\left(\mathrm{~cm}^{3} \mathrm{~mol}^{-1}\right)$. The inlet concentration of the reactor is obtained through mass balance.

The mathematical modeling of the mixer and the HDT reactor are described in the following sections:

\section{Mass Balance}

In the mixer - Overall and component mass balances in the mixer (Figure 1) are given by Equation 1 and Equation 2, respectively.

$$
\begin{aligned}
\mathrm{F}_{\text {total feed }}=\mathrm{F}_{\text {Oil A }}+\mathrm{F}_{\text {Oil b }}+\mathrm{F}_{\text {Oil C }} \\
\begin{aligned}
\mathrm{C}_{\text {total feed }} \mathrm{F}_{\text {total feed }} & =\mathrm{C}_{\text {Oil A }} \mathrm{F}_{\text {Oil A }}+\mathrm{C}_{\text {Oil B }} \mathrm{F}_{\text {Oil b }}+ \\
& +\mathrm{C}_{\text {Oil C }} \mathrm{F}_{\text {Oil C }}
\end{aligned}
\end{aligned}
$$


where $\mathrm{F}_{\text {total feed }}\left(\mathrm{cm}^{3} \mathrm{~s}^{-1}\right)$ is the total feed flowrate of the reactor; $\mathrm{F}_{\text {Oil A }}\left(\mathrm{cm}^{3} \mathrm{~s}^{-1}\right), \mathrm{F}_{\text {Oil B }}\left(\mathrm{cm}^{3} \mathrm{~s}^{-1}\right)$ and $\mathrm{F}_{\text {Oil C }}\left(\mathrm{cm}^{3}\right.$ $\left.\mathrm{s}^{-1}\right)$ are respectively the feed flowrates of oils A, B and $\mathrm{C}$ in the mixer; $\left.\mathrm{C}_{\text {total feed }}(\mathrm{mol} \mathrm{cm})^{-3}\right)$ is the inlet sulfur concentration of the reactor; $\mathrm{C}_{\mathrm{Oil}}\left(\mathrm{mol} \mathrm{cm}^{-3}\right)$, $\mathrm{C}_{\text {Oil B }}\left(\mathrm{mol} \mathrm{cm}^{-3}\right)$ and $\left.\mathrm{C}_{\text {Oil C }}(\mathrm{mol} \mathrm{cm})^{-3}\right)$ are the sulfur concentrations of the oils in the mixer.

In the reactor - The following mass balance equations in the TBR were based on the work of Mederos and Ancheyta (2007).

- Gas phase:

$-\mathrm{u}_{\mathrm{G}} \frac{\mathrm{dp}_{\mathrm{i}}^{\mathrm{G}}}{\mathrm{dz}}-\mathrm{RT}_{\mathrm{G}} \mathrm{k}_{\mathrm{i}}^{\mathrm{L}} \mathrm{a}_{\mathrm{L}}\left(\frac{\mathrm{p}_{\mathrm{i}}^{\mathrm{G}}}{\mathrm{H}_{\mathrm{i}}}-\mathrm{C}_{\mathrm{i}}^{\mathrm{L}}\right)=0$

$\mathrm{i}=\mathrm{H}_{2}$ and $\mathrm{H}_{2} \mathrm{~S}$

where $\mathrm{p}_{\mathrm{i}}^{\mathrm{G}}(\mathrm{MPa})$ is the partial pressure of component $\mathrm{i} ; \mathrm{u}_{\mathrm{G}}\left(\mathrm{cm} \mathrm{s}^{-1}\right)$ is the gas velocity; $\mathrm{z}(\mathrm{cm})$ is the spatial variable; $R\left(\mathrm{~J} \mathrm{~mol}^{-1} \mathrm{~K}^{-1}\right)$ is the gas constant; $\mathrm{T}_{\mathrm{G}}(\mathrm{K})$ is the temperature of the gas phase; $\mathrm{k}_{\mathrm{i}}^{\mathrm{L}}(\mathrm{cm} / \mathrm{s})$ is the mass transfer coefficient of the component $i$ at the liquid interface; $a_{L}\left(\mathrm{~cm}^{-1}\right)$ is the specific area at the liquid interface; $\mathcal{H}_{\mathrm{i}}\left(\mathrm{MPa} \mathrm{cm} \mathrm{mol}^{-1}\right)$ is the constant of Henry's law for component i; $\mathrm{C}_{i}^{\mathrm{L}}\left(\mathrm{mol} \mathrm{cm}^{-3}\right)$ is the concentration of component $\mathrm{i}$ in the liquid phase; $\mathrm{H}_{2}$ is hydrogen gas; $\mathrm{H}_{2} \mathrm{~S}$ is the sulfhydric gas.

- Liquid phase:

$-u_{L} \frac{d C_{i}^{L}}{d z}+\varepsilon_{L} D_{a}^{L} \frac{d^{2} C_{i}^{L}}{d z^{2}}+k_{i}^{L} a_{L}\left(\frac{p_{i}^{G}}{\mathcal{H}_{i}}-C_{i}^{L}\right)-k_{i}^{S} a_{S}\left(C_{i}^{L}-C_{i}^{S}\right)=0$

$\mathrm{i}=\mathrm{H}_{2}$ and $\mathrm{H}_{2} \mathrm{~S}$

$-\mathrm{u}_{\mathrm{L}} \frac{\mathrm{dC}_{\mathrm{i}}^{\mathrm{L}}}{\mathrm{dz}}+\varepsilon_{\mathrm{L}} \mathrm{D}_{\mathrm{a}}^{\mathrm{L}} \frac{\mathrm{d}^{2} \mathrm{C}_{\mathrm{i}}^{\mathrm{L}}}{\mathrm{dz}^{2}}-\mathrm{k}_{\mathrm{i}}^{\mathrm{S}} \mathrm{a}_{\mathrm{S}}\left(\mathrm{C}_{\mathrm{i}}^{\mathrm{L}}-\mathrm{C}_{\mathrm{i}}^{\mathrm{S}}\right)=0$

$\mathrm{i}=\mathrm{S}$ and $\mathrm{HC}$

where $\varepsilon_{\mathrm{L}}$ is the liquid phase holdup; $\mathrm{u}_{\mathrm{L}}\left(\mathrm{cm} \mathrm{s}^{-1}\right)$ is the velocity of the liquid; $\mathrm{D}^{\mathrm{L}}\left(\mathrm{cm}^{2} \mathrm{~s}^{-1}\right)$ is the mass dispersion coefficient in the liquid phase; $\mathrm{k}_{\mathrm{i}}^{\mathrm{S}}\left(\mathrm{cm} \mathrm{s}^{-1}\right)$ is the mass transfer coefficient of component $i$ at the interface of the solid phase; $a_{\mathrm{S}}\left(\mathrm{cm}^{-1}\right)$ is the specific area at the interface of the solid phase; $\mathrm{C}_{i}^{\mathrm{S}}\left(\mathrm{mol} \mathrm{cm}^{-3}\right)$ is the concentration of component $\mathrm{i}$ in the solid phase; $\mathrm{S}$ in subscript i represents the sulfur compound and HC represents the hydrocarbons.

- Solid phase:

$\mathrm{k}_{\mathrm{i}}^{\mathrm{S}} \mathrm{a}_{\mathrm{S}}\left(\mathrm{C}_{\mathrm{i}}^{\mathrm{L}}-\mathrm{C}_{\mathrm{i}}^{\mathrm{S}}\right) \pm \rho_{\mathrm{B}} \xi \eta_{\mathrm{HDS}} \mathrm{r}_{\mathrm{HDS}}=0$

$\mathrm{i}=\mathrm{H}_{2}, \mathrm{H}_{2} \mathrm{~S}, \mathrm{~S}$ and $\mathrm{HC}$

in which $\mathrm{r}_{\mathrm{HDS}}\left(\mathrm{mol} \mathrm{g}^{-1} \mathrm{~s}^{-1}\right)$ is the rate of the HDS reaction; the " \pm " sign means "-" for reagents and "+" for the products; $\rho_{\mathrm{B}}\left(\mathrm{g} \mathrm{cm}^{-3}\right)$ is the bulk density; $\xi$ is the volume fraction of the diluted bed; $\eta_{\mathrm{HDS}}$ is the catalytic efficiency for the HDS reaction.

The following boundary conditions were applied to the differential equations:

At $\mathrm{z}=0$, the partial pressures of the gaseous components at the inlet of the reactor are:

$\mathrm{p}_{\mathrm{i}}^{\mathrm{G}}=\left(\mathrm{p}_{\mathrm{i}}^{\mathrm{G}}\right)_{0}, \mathrm{i}=\mathrm{H}_{2}$ and $\mathrm{H}_{2} \mathrm{~S}$

The concentrations of the components in the liquid phase at the inlet of the reactor $(\mathrm{z}=0)$ were based on Danckwerts boundary conditions (Danckwerts, 1995):

$C_{i}^{L}=\left(C_{i}^{L}\right)_{0}+\left(\frac{L}{P e}\right) \frac{d C_{i}^{L}}{d z} \quad i=H_{2}, H_{2} S, S$ and $H C$

and at $\mathrm{z}=\mathrm{L}$ :

$\frac{\mathrm{dC}_{\mathrm{i}}^{\mathrm{L}}}{\mathrm{dz}}=0$

in which the Peclet number $(\mathrm{Pe})$ was calculated by the Hochman-Effort correlation (Mederos and Ancheyta, 2007) for cocurrent pilot operation, through Equation 7.

$\mathrm{Pe}=0.034\left(\operatorname{Re}_{\mathrm{liq}}\right)^{0.5} 10^{0.003\left(\mathrm{Re}_{\mathrm{gas}}\right)}$

where $\mathrm{Re}_{\mathrm{liq}}$ and $\mathrm{Re}_{\text {gas }}$ are the Reynolds number of the liquid and gas phases, respectively.

\section{Energy Balance}

In the mixer - The energy balance in the mixer (Figure 1) is given by Equation 8.

$$
\mathrm{F}_{\text {total feed }} \mathrm{h}_{\text {total feed }}+\mathrm{Q}=\mathrm{F}_{\text {Oil A }} \mathrm{h}_{\text {Oil A }}+\mathrm{F}_{\text {Oil B }} \mathrm{h}_{\text {Oil B }}+\mathrm{F}_{\text {Oil C }} \mathrm{h}_{\text {Oil C }}(8)
$$

where $\mathrm{h}_{\text {total feed }}\left(\mathrm{kJ} \mathrm{kmol}^{-1}\right)$ is the enthalpy of the feed stream to the reactor; $\mathrm{Q}(\mathrm{kW})$ is the heat source in the mixer; $\mathrm{h}_{\text {Oil A }}\left(\mathrm{kJ} \mathrm{kmol}^{-1}\right), \mathrm{h}_{\text {Oil B }}\left(\mathrm{kJ} \mathrm{kmol}^{-1}\right)$ and $\mathrm{h}_{\text {Oil C }}(\mathrm{kJ}$ $\mathrm{kmol}^{-1}$ ) are respectively the enthalpies of the oils A, B and $\mathrm{C}$ in the mixer.

In the reactor - The energy balance equations in the TBR were based on the work of Mederos and Ancheyta (2007).

- Gas phase:

$-\mathrm{u}_{\mathrm{G}} \rho_{\mathrm{G}} \mathrm{C}_{\mathrm{P}}^{\mathrm{G}} \frac{\mathrm{dT}_{\mathrm{G}}}{\mathrm{dz}}-\mathrm{h}_{\mathrm{GL}} \mathrm{a}_{\mathrm{L}}\left(\mathrm{T}_{\mathrm{G}}-\mathrm{T}_{\mathrm{L}}\right)=0$

- Liquid phase:

$-\mathrm{u}_{\mathrm{L}} \rho_{\mathrm{L}} \mathrm{C}_{\mathrm{P}}^{\mathrm{L}} \frac{\mathrm{dT}_{\mathrm{L}}}{\mathrm{dz}}+\mathrm{h}_{\mathrm{GL}} \mathrm{a}_{\mathrm{L}}\left(\mathrm{T}_{\mathrm{G}}-\mathrm{T}_{\mathrm{L}}\right)-\mathrm{h}_{\mathrm{LS}} \mathrm{a}_{\mathrm{S}}\left(\mathrm{T}_{\mathrm{L}}-\mathrm{T}_{\mathrm{S}}\right)$ 
- Solid phase:

$\mathrm{h}_{\mathrm{LS}} \mathrm{a}_{\mathrm{S}}\left(\mathrm{T}_{\mathrm{L}}-\mathrm{T}_{\mathrm{S}}\right)+\rho_{\mathrm{B}} \eta_{\mathrm{HDS}} \mathrm{r}_{\mathrm{HDS}}\left(-\Delta \mathrm{H}_{\mathrm{R}}^{\mathrm{HDS}}\right)=0$

where $\rho_{\mathrm{G}}\left(\mathrm{g} \mathrm{cm}^{-3}\right), \rho_{\mathrm{L}}\left(\mathrm{g} \mathrm{cm}^{-3}\right)$ and $\rho_{\mathrm{S}}\left(\mathrm{g} \mathrm{cm}^{-3}\right)$ are respectively the gas, liquid and solid phases densities; $\mathrm{C}_{\mathrm{p}}{ }^{\mathrm{G}}\left(\mathrm{J} \mathrm{g}^{-1} \mathrm{~K}^{-1}\right), \mathrm{C}_{\mathrm{p}}^{\mathrm{L}}\left(\mathrm{J} \mathrm{g}^{-1} \mathrm{~K}^{-1}\right)$ and $\mathrm{C}_{\mathrm{p}}^{\mathrm{S}}\left(\mathrm{J} \mathrm{g} \mathrm{g}^{-1} \mathrm{~K}^{-1}\right)$ are respectively the specific heat capacities of the gas, liquid and solid; $\mathrm{h}_{\mathrm{GL}}\left(\mathrm{J} \mathrm{s}^{-1} \mathrm{~cm}^{-2} \mathrm{~K}^{-1}\right)$ and $\mathrm{h}_{\mathrm{LS}}\left(\mathrm{J} \mathrm{s}^{-1} \mathrm{~cm}^{-2}\right.$ $\mathrm{K}^{-1}$ ) are respectively heat transfer coefficients at the gas-liquid and liquid-solid interfaces; $T_{L}(K)$ and $\mathrm{T}_{\mathrm{S}}(\mathrm{K})$ are respectively the liquid and solid phases temperatures; $\Delta_{\mathrm{R}}{ }^{\mathrm{HDS}}\left(\mathrm{J} \mathrm{mol}^{-1}\right)$ is the heat of the HDS reaction.

The following boundary conditions were applied to the differential equations: the temperatures of each phase at the inlet of the reactor (at $\mathrm{z}=0$ ) are:

$\mathrm{T}_{\mathrm{L}}=\mathrm{T}_{\mathrm{S}}=\mathrm{T}_{\mathrm{O}}$

$\mathrm{T}_{\mathrm{G}}=653 \mathrm{~K}$

\section{Kinetic Model}

We consider that the oil fraction feeding the mixer contains a great amount of organic sulfur compounds and, during reaction, the hydrogen sulfide is adsorbed at the active catalyst sites. In this study, the HDS reaction was considered irreversible and the organic sulfur content and the hydrogen concentration have a positive effect (Korsten and Hoffman, 1999). Usually the overall HDS reaction is represented by the practical and generalized stoichiometric equation. This approach is widely accepted and accumulates the HDS reaction of all sulfur compounds (Dibenzothiophene-DBT and its alkyl-derivates) in a single expression (Korsten and Hoffman, 1999; Bhaskar et al., 2004; Rodríguez and Ancheyta, 2004; Mederos and Ancheyta, 2007; Alvarez and Ancheyta, 2008a). The HDS reaction model is of the Langmuir-Hinshelwood type, which takes into account the inhibitory effects of $\mathrm{H}_{2} \mathrm{~S}$ formation by including an adsorption equilibrium constant for $\mathrm{H}_{2} \mathrm{~S}$ described by the van't Hoff equation to relate the equilibrium coefficient with temperature on the adsorption of the hydrogen sulphide on the active sites of the catalyst (Korsten and Hoffmann, 1996; Mederos and Ancheyta, 2007; Alvarez and Ancheyta, 2008b; Kallinikos et al., 2010; Alvarez et al., 2011). The reaction rate of HDS occurs according to Equation 12.

$\mathrm{r}_{\mathrm{HDS}}=\frac{\mathrm{k}_{\mathrm{HDS}} \mathrm{C}_{\mathrm{S}}^{\mathrm{S}}\left(\mathrm{C}_{\mathrm{H}_{2}}^{\mathrm{S}}\right)^{0,45}}{\left[1+\mathrm{k}_{\mathrm{H}_{2} \mathrm{~S}}\left(\mathrm{C}_{\mathrm{H}_{2} \mathrm{~S}}^{\mathrm{S}}\right)\right]^{2}}$

where $\mathrm{r}_{\mathrm{HDS}}\left(\mathrm{mol} \mathrm{g}^{-1} \mathrm{~s}^{-1}\right)$ is the rate of HDS reaction; $\mathrm{k}_{\mathrm{HDS}}\left(\mathrm{cm}^{3} \mathrm{~g}^{-1} \mathrm{~s}^{-1}\right)\left(\mathrm{cm}^{3} \mathrm{~mol}^{-1}\right)^{0.45}$ is the apparent constant of the HDS reaction; $\mathrm{k}_{\mathrm{H}_{2} \mathrm{~S}}\left(\mathrm{~cm}^{3} \mathrm{~mol}^{-1}\right)$ is the adsorption constant for $\mathrm{H}_{2} \mathrm{~S}$;

\section{Numerical Integration}

The system of differential equations describing the heat and mass transfers in the reactor was transformed into a set of algebraic equations, using the finite difference method.

The number of discretization points required for the numerical method used to obtain the satisfactory solution was determined using the mesh convergence criterion the absolute difference between the values of the process variables obtained at the discretization points of the refinement mesh $\mathrm{k}+1$ and the values obtained at the discretization points by the refinement mesh $\mathrm{k}$ were less than $10^{-5}$.

The algebraic equations were solved using SUite of Nonlinear and Differential/ALgebraic equation Solvers - sundial algorithms - (Hindmarsh et al., 2005), using EMSO (Environment for Modeling, Simulation and Optimization) software (Soares and Secchi, 2003) as a platform for modelling, simulations and optimization of the process.

\section{Process Optimization}

Current Brazilian legislation establishes diesel to present a maximum of $10 \mathrm{ppm}$ of sulfur concentration. An optimization problem was proposed to minimize the operating cost of the HDS process, subject to the maximum allowed sulfur concentration in the final product. EMSO process simulator was used to simulate and optimize the problem, and the IPOPT algorithm (Wächter and Biegler, 2006) was used to solve the optimization problem.

Limitations on variables such as temperature, pressure and LHSV of the reaction mixture should be taken into account, as they influence the performance of hydrotreatment. Many researchers have shown that the reaction temperature can vary greatly depending on the characteristics of the charge. Korsten and Hoffman (1999) studied the HDS reaction at temperatures ranging from $350^{\circ} \mathrm{C}$ to $400^{\circ} \mathrm{C}$, showing that the analyses can be done at higher temperatures depending on the characteristics of the feedstock. These authors also analyzed the effects of pressure on the HDS reaction, showing that the increase in pressure favors the reaction with limits that depend on the nature of the feed and the catalyst. The authors pointed out that the HDS reaction, under the conditions studied, showed good performance between 6 and $10 \mathrm{MPa}$. The authors analyzed the LHSV between 0.9-4.8 $\left(\mathrm{h}^{-1}\right)$ showing that the smaller values favor the HDS reaction. Similar analyzes and conclusions have been reported in the literature (Mederos and Ancheyta, 2007; Al-Daous 
and Ali, 2012; Novaes et al., 2017; Tao et al., 2017).

Based on the literature in the case studies implemented in this work, the limits on the optimization variables were chosen. The Objective Function (OF) given by Equation 13 was used to represent the costs of the process.

Optimization problem:

Minimize:

$\mathrm{OF}=\sigma_{\text {Oil A }} \mathrm{F}_{\mathrm{Oil} \mathrm{A}}+\sigma_{\mathrm{Oil} \mathrm{B}} \mathrm{F}_{\mathrm{Oil} \mathrm{B}}+\sigma_{\mathrm{OilC}} \mathrm{F}_{\mathrm{Oil} \mathrm{C}}+\sigma_{\mathrm{H}_{2}} \mathrm{~F}_{\mathrm{H}_{2}}+\sigma_{\mathrm{Q}} \mathrm{Q}$

\section{Subject to:}

Equality constraints: Equations 1 to 12 .

Inequality constraints:

$$
\begin{aligned}
& 1 \times 10^{-6}\left(\frac{\mathrm{cm}^{3}}{\mathrm{~s}}\right) \leq \mathrm{F}_{\text {Oil A }} \leq \mathrm{F}_{\text {total feed }} \\
& 1 \times 10^{-6}\left(\frac{\mathrm{cm}^{3}}{\mathrm{~s}}\right) \leq \mathrm{F}_{\text {Oil B }} \leq \mathrm{F}_{\text {total feed }} \\
& 1 \times 10^{-6}\left(\frac{\mathrm{cm}^{3}}{\mathrm{~s}}\right) \leq \mathrm{F}_{\text {Oil C }} \leq \mathrm{F}_{\text {total feed }} \\
& 0.05\left(\frac{\mathrm{cm}}{\mathrm{s}}\right) \leq \mathrm{u}_{\mathrm{G}} \leq 1.0\left(\frac{\mathrm{cm}}{\mathrm{s}}\right) \\
& 653(\mathrm{~K}) \leq \mathrm{T}_{\mathrm{O}} \leq 710(\mathrm{~K}) \\
& 0(\mathrm{ppm})<\mathrm{CS}_{\text {out }} \leq 10(\mathrm{ppm})
\end{aligned}
$$

where OF (US\$ $\mathrm{h}^{-1}$ ) is the Objective Function; $\sigma_{\text {Oil A }}$ $\left(\mathrm{US} \$ \mathrm{~cm}^{-3}\right), \sigma_{\text {Oil в }}\left(\mathrm{US} \$ \mathrm{~cm}^{-3}\right), \sigma_{\text {Oil C }}\left(\mathrm{US} \$ \mathrm{~cm}^{-3}\right)$ and $\sigma_{\mathrm{H}_{2}}\left(\mathrm{US} \$ \mathrm{~cm}^{-3}\right)$ are the costs of the fed compounds, $\sigma_{\mathrm{O}}$ (US\$ kJ-1) is the cost of supplied heat; $\mathrm{F}_{\mathrm{H}_{2}}\left(\mathrm{~cm}^{3} \mathrm{~s}^{-1}\right)$ is the feed flowrate of hydrogen in the reactor; $\mathrm{T}_{\mathrm{O}}(\mathrm{K})$ is the inlet temperature of the reactor; $\mathrm{CS}_{\text {out }}(\mathrm{ppm})$ is the sulfur outlet concentration of the reactor.

The constraints of the optimization problem were chosen observing the physical conditions of the process. In Table 2, the information about the size of the optimization problem is provided.

Table 2. Informations about the proposed optimization problem.

\begin{tabular}{lc}
\hline \multicolumn{1}{c}{ Details of the optimization problem } & Values \\
\hline Number of equality constraints & 4980 \\
Number of inequality constraints & 6 \\
Degrees of freedom of the optimization problem & 4 \\
Number of discrete points & 110 \\
\hline
\end{tabular}

\section{RESULTS AND DISCUSSION}

\section{Model Validation}

Operating data from the pilot-scale HDT process were extracted from the work of Mederos and Ancheyta (2007) to validate the model addressed in this work. The authors considered a single feed diesel HDT process and the hypotheses presented in Section 2 , with $\mathrm{u}_{\mathrm{G}}=0.028 \mathrm{~cm} / \mathrm{s}, \mathrm{u}_{\mathrm{L}}=1.75 \times 10^{-2} \mathrm{~cm} / \mathrm{s}$, where $\mathrm{u}_{\mathrm{L}}$ is the surface velocity of the liquid phase through the $\mathrm{TBR}, \mathrm{T}_{\mathrm{o}}=653 \mathrm{~K}$ and $\mathrm{P}=5.3 \mathrm{MPa}$.

The partial pressure profiles of the gaseous compounds, $\mathrm{H}_{2}$ and $\mathrm{H}_{2} \mathrm{~S}$, and the sulfur concentration in the liquid phase along the reactor can be seen in Fig. 2a, Fig. 2b and Fig. 3, respectively. It is observed that the results obtained in the simulations are similar to the literature, indicating that the reactor model is representative.

Mederos and Ancheyta (2007) discussed about some HDT operation conditions and showed that cocurrent operation with $\mathrm{H}_{2}$ saturated oils is the approach which better fits the experimental data. The model parameters provided by these authors were used to validate the modeling in this work (Fig. 2 and Fig. 3). We observed that the profiles obtained in the simulations of this work were above those predicted in the simulations by Mederos and Ancheyta (2007), this can occur due to the numerical method used, as well as due to the numerical precision of the result of the mathematical model of the process, as shown in Figs. 2 and 3.

\section{Sensitivity Analysis}

A sensitivity analysis was carried out within the constraints of the process in order to understand the behavior of the objective function (OF).

Fig. 4 shows that costs are lowered when lower $\mathrm{T}_{\mathrm{o}}$ values are considered, implying a lower energy supply to heat the oil feed. The objective function is also decreased when the velocity of the hydrogen gas is reduced, so that there is a smaller gas flow feeding the system (Fig. 4b). Then the objective function decreases as $\mathrm{T}_{\mathrm{o}}$ and $\mathrm{u}_{\mathrm{G}}$ decrease. In Fig. 4b, the feed flowrate of oil $\mathrm{A}\left(\mathrm{F}_{\mathrm{A}}\right)$ was kept constant and the feed flowrate of oil $\mathrm{C}\left(\mathrm{F}_{\mathrm{C}}\right)$ was varied from $0.01 \mathrm{~cm}^{3} / \mathrm{s}$ to $0.04 \mathrm{~cm}^{3} / \mathrm{s}$, and thus the feed flowrate of oil $\mathrm{B}\left(\mathrm{F}_{\mathrm{B}}\right)$ was obtained from the mass balance. It is observed that the variation in $\mathrm{F}_{\mathrm{C}}$ does not cause variations in the value of the objective function for the tested operating conditions, showing no sensitivity (for each $\mathrm{F}_{\mathrm{C}}$ value, surfaces that overlap were generated). These details can be seen in Fig. 4a, where, for each value of $T_{0}$, values of the objective function are constant with the variations in $\mathrm{F}_{\mathrm{A}}$ and $\mathrm{F}_{\mathrm{C}}$, 


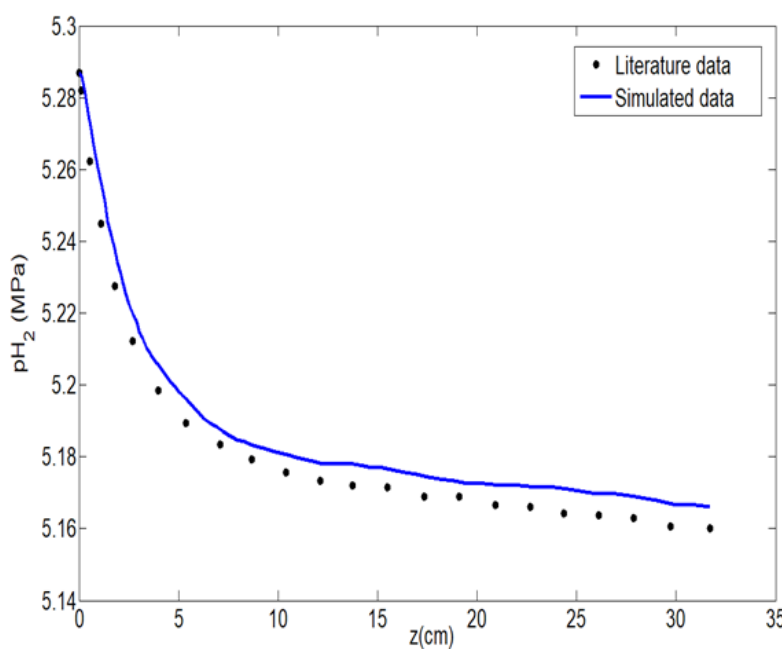

(a)

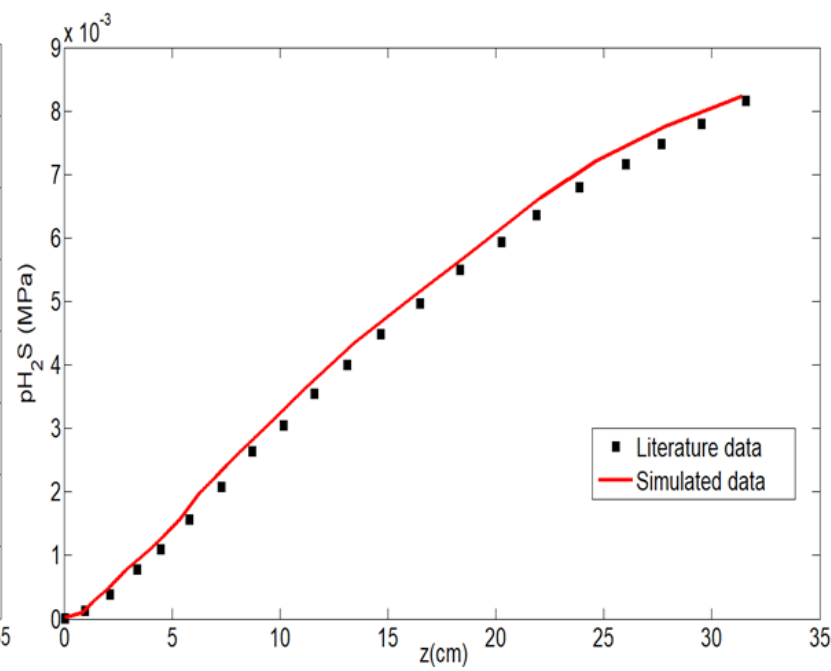

(b)

Figure 2. a) Profiles of partial pressures of the $H_{2}$ along the reactor: continuous line, data obtained from the simulations; discontinuous line, data obtained from Mederos and Ancheyta (2007). b) Profiles of partial pressures of $\mathrm{H}_{2} \mathrm{~S}$ along the reactor: continuous line, results obtained from the simulations; discontinuous line, data obtained from Mederos and Ancheyta (2007).

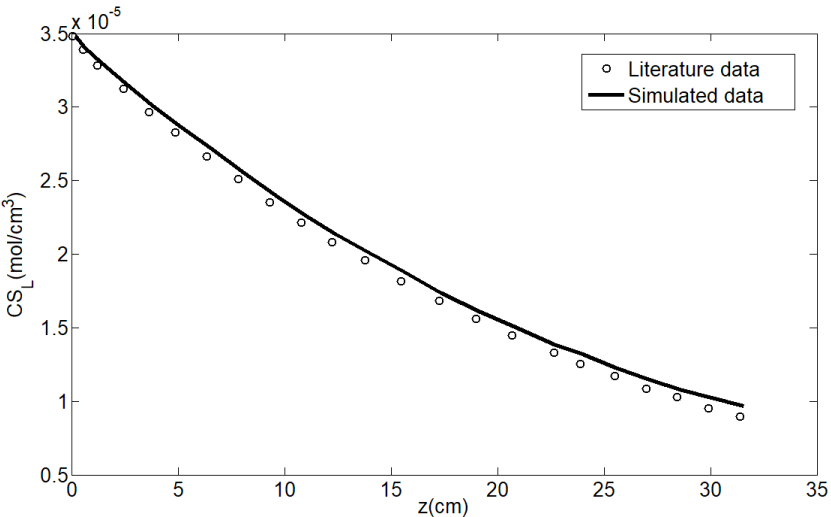

Figure 3. Profile of sulfur concentration in the liquid mixture $\left(\mathrm{CS}_{\mathrm{L}}\right)$ along the reactor: continuous line, results obtained from the simulations; discontinuous line, data obtained from Mederos and Ancheyta (2007).

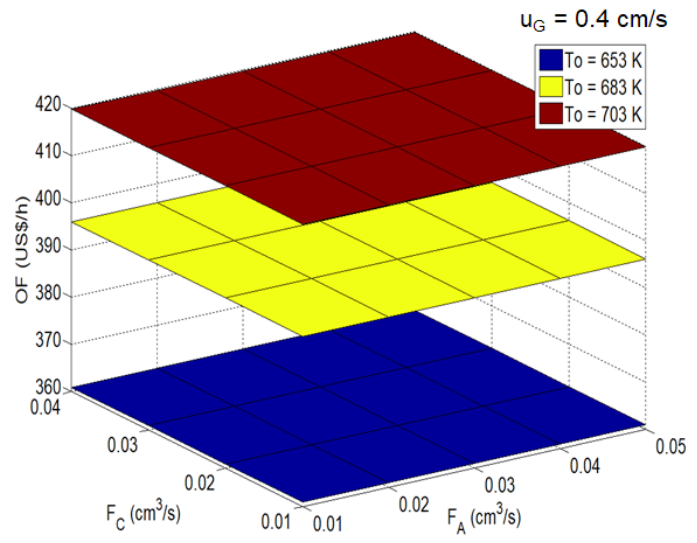

(a) since the structure of the objective function causes $F_{B}$ to compensate for changes in $\mathrm{F}_{\mathrm{A}}$ and $\mathrm{F}_{\mathrm{C}}$, generating parallel planes to the axes of $\mathrm{F}_{\mathrm{A}}$ and $\mathrm{F}_{\mathrm{C}}$. The highest sensitivities observed were for variations of $\mathrm{u}_{\mathrm{G}}$ and $\mathrm{T}_{\mathrm{o}}$ (Fig. 4b).

Fig. 5 shows the behavior of the sulfur concentration at the exit of the reactor as function of the feed flowrates of oils in the mixer. It is observed that the sulfur concentration is influenced by the manipulation of the inlet temperature of the reactor. The presence of sulfur compounds decreases with a temperature increase. It is also observed that the flow of oils at the entrance of the system impacts the quantity of sulfur compounds at the exit of the system. In these cases, the highest sensitivities are observed when the temperature is varied.

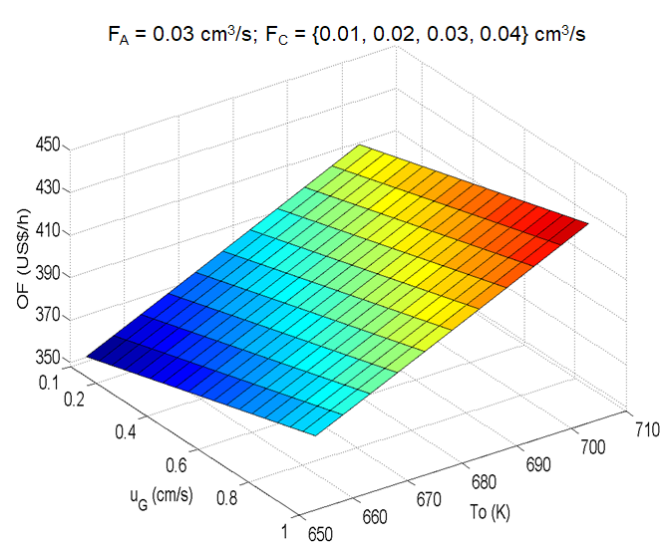

(b)

Figure 4. a) Objective Function (OF) as a function of the oil flow rate at the inlet of the mixer, with the gas surface velocity $\left(\mathrm{u}_{\mathrm{G}}\right)$ equal to $0.4 \mathrm{~cm} / \mathrm{s}$ and $\mathrm{T}$ equal to $653 \mathrm{~K}, 683 \mathrm{~K}$ and $703 \mathrm{~K}$.; b) Objective Function (OF) as a function of the gas velocity $\left(\mathrm{u}_{\mathrm{G}}\right)$ and the reactor inlet temperature $\left(\mathrm{T}_{\mathrm{o}}\right)$, with the feed flowrate of oil $\mathrm{A}\left(\mathrm{F}_{\mathrm{A}}\right)$ kept constant, and the feed flowrate of oil $\mathrm{C}\left(\mathrm{F}_{\mathrm{C}}\right)$ varying between $0.01 \mathrm{~cm}^{3} / \mathrm{s}$ and $0.04 \mathrm{~cm}^{3} / \mathrm{s}$. 


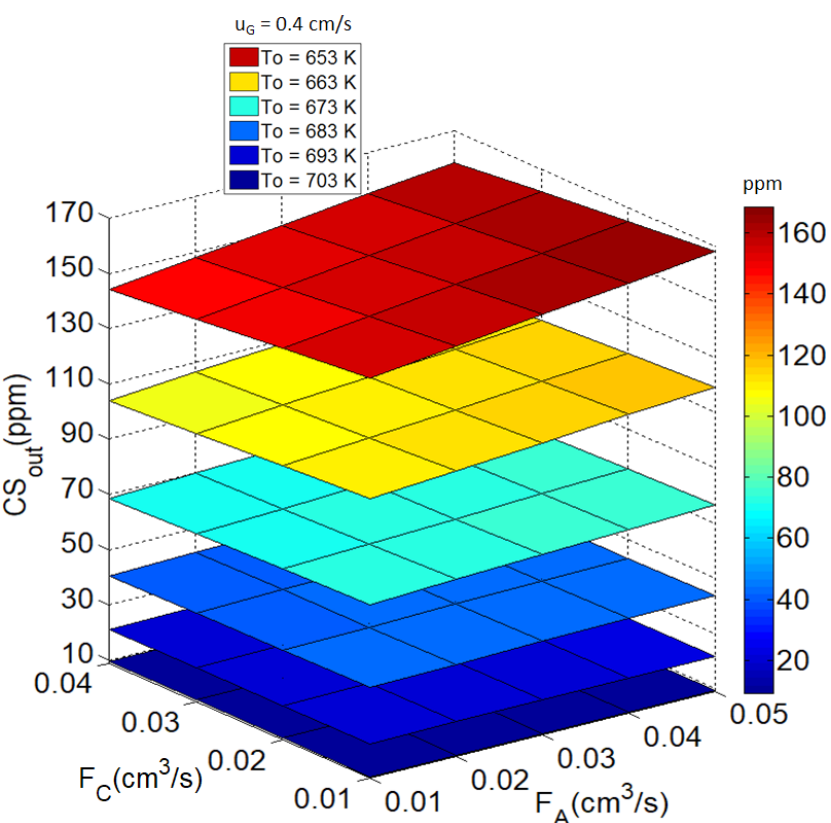

Figure 5. Sulfur concentration at the outlet of the reactor $\left(\mathrm{CS}_{\text {out }}\right)$ as a function of the feed flowrates of oils in the mixer, with the gas surface velocity $\left(\mathrm{u}_{\mathrm{C}}\right)$ equal to $0.4 \mathrm{~cm} / \mathrm{s}$ and $\mathrm{T}_{\mathrm{o}}$ ranging from $653 \mathrm{~K}$ to $703 \mathrm{~K}$.

The concentration of $10 \mathrm{ppm}$ of sulfur at the reactor outlet was obtained between $\mathrm{T}_{\mathrm{o}}=702 \mathrm{~K}$ and $\mathrm{T}_{\mathrm{o}}=703$ $\mathrm{K}$, considering $\mathrm{u}_{\mathrm{G}}=0.4 \mathrm{~cm} / \mathrm{s}$ (Fig. 5 and Fig. 6). These operating conditions favor the HDS reaction rate. In Fig. 6, the concentration of sulfur at the exit of the reactor is around $10 \mathrm{ppm}$, indicating that, in this way, the product specification can be achieved.

Fig. 7 shows behavior of sulfur concentration at the exit of the reactor, varying the gas velocity $\left(\mathrm{u}_{\mathrm{G}}\right)$ and the reactor inlet temperature $\left(\mathrm{T}_{\mathrm{o}}\right)$. The flow rate of oil A $\left(\mathrm{F}_{\mathrm{A}}\right)$ was kept constant at $0.03 \mathrm{~cm}^{3} / \mathrm{s}$, the flow rate of oil $\mathrm{C}\left(\mathrm{F}_{\mathrm{C}}\right)$ was varied between $0.01 \mathrm{~cm}^{3} / \mathrm{s}$ and 0.04 $\mathrm{cm}^{3} / \mathrm{s}$, the oil flow rate $\mathrm{B}\left(\mathrm{F}_{\mathrm{B}}\right)$ was calculated from the

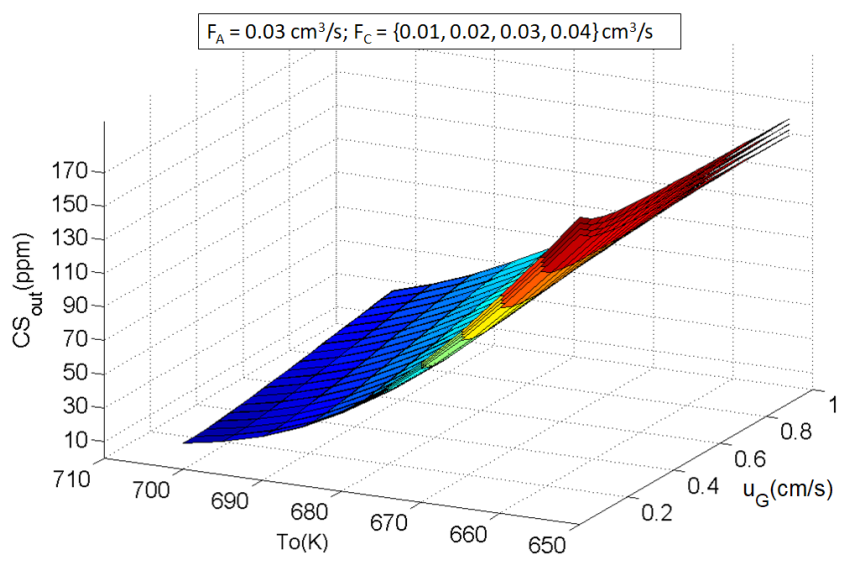

Figure 7. Sulfur concentration as a function of the gas velocity $\left(\mathrm{u}_{\mathrm{G}}\right)$ ant the inlet temperature (To) of the reactor, with the flow of oil $\mathrm{A}\left(\mathrm{F}_{\mathrm{A}}\right)$ kept constant equal to $0.03 \mathrm{~cm}^{3} / \mathrm{s}$, the flow of oil $\mathrm{C}\left(\mathrm{F}_{\mathrm{C}}\right)$ varying between $0.01 \mathrm{~cm}^{3} / \mathrm{s}$ and $0.04 \mathrm{~cm}^{3} / \mathrm{s}$ and the flow rate of oil $\mathrm{B}$ is obtained from the mass balance.

mass balance by Equation 1, and the inlet flow rate of the reactor was kept constant according to Table 1. Between the temperatures of $650 \mathrm{~K}$ and $680 \mathrm{~K}$, the sensitivity is greater as to the variation of $\mathrm{u}_{\mathrm{G}}$. From $680 \mathrm{~K}$, the response is more sensitive to temperature variation. The conditions for obtaining the product with concentrations around $10 \mathrm{ppm}$ of sulfur are observed from the temperature of $700 \mathrm{~K}$ and gas velocity between $0.1 \mathrm{~cm} / \mathrm{s}$ and $0.5 \mathrm{~cm} / \mathrm{s}$. It is observed that the variations in $\mathrm{F}_{\mathrm{C}}$ cause small differences among the surfaces observed in Fig. 7, since the highest sensitivities are observed in the variations of $\mathrm{T}_{\mathrm{o}}$ and $\mathrm{u}_{\mathrm{G}}$.

\section{Optimization Results}

In Table 3, it can be verified that the optimization problem generated a product that meets the specification with a sulfur concentration of $9.84 \mathrm{ppm}$.

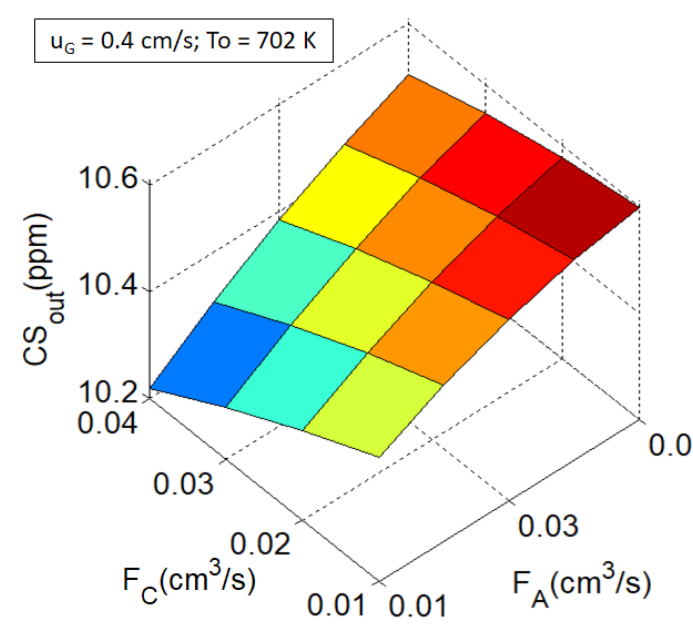

(a)

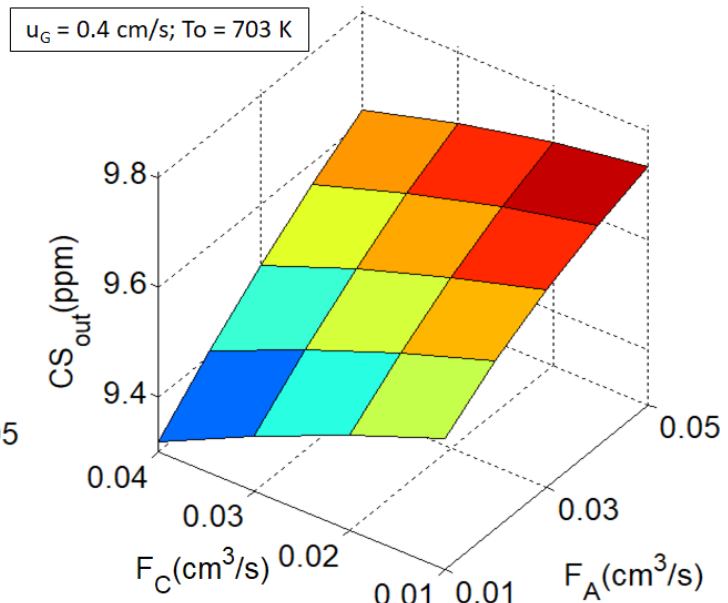

(b)

Figure 6. Sulfur concentration at the outlet of the reactor $\left(\mathrm{CS}_{\text {out }}\right)$ as a function of the feed flowrates of oils in the mixer, with the gas surface velocity $\left(\mathrm{u}_{\mathrm{G}}\right)$ and To: a) $\left.\mathrm{u}_{\mathrm{G}}=0.4 \mathrm{~cm} / \mathrm{s}, \mathrm{T}_{\mathrm{o}}=702 \mathrm{~K} ; \mathrm{b}\right) \mathrm{u}_{\mathrm{G}}=0.4 \mathrm{~cm} / \mathrm{s}, \mathrm{T}_{\mathrm{o}}=703 \mathrm{~K}$. 
Table 3. Results of the proposed optimization problem.

\begin{tabular}{lcc}
\hline \multicolumn{1}{c}{ Informations } & $\begin{array}{c}\text { Original } \\
\text { Solution }\end{array}$ & $\begin{array}{c}\text { Optimized } \\
\text { Solution }\end{array}$ \\
\hline $\mathrm{u}_{\mathrm{G}}(\mathrm{cm} / \mathrm{s})$ & 0.28 & 0.21 \\
$\mathrm{~F}_{\mathrm{A}}\left(\mathrm{cm}^{3} / \mathrm{s}\right)$ & 0.03 & 0.018 \\
$\mathrm{~F}_{\mathrm{B}}\left(\mathrm{cm}^{3} / \mathrm{s}\right)$ & 0.05 & 0.022 \\
$\mathrm{~F}_{\mathrm{C}}\left(\mathrm{cm}^{3} / \mathrm{s}\right)$ & 0.02 & 0.06 \\
$\mathrm{~T}_{\mathrm{o}}(\mathrm{K})$ & 653 & 699 \\
$\mathrm{OF}(\mathrm{US} \$ / \mathrm{h})$ & 356.5 & 404.09 \\
Sulfur concentration at the exit of & 160 & 9.84 \\
the reactor $(\mathrm{ppm})$ & & \\
\hline
\end{tabular}

The optimized value of the objective function was $404.09 \mathrm{US} \$ / \mathrm{h}$, which is a minimum value for the desired product specification. As compared to the original value, there was an increase in reactor input temperature and variations in gas velocity and oil flow rates.

Simulations of the optimization problem showed that a feasible region was reached (as seen in Fig. 5 to Fig. 7), in which the specified diesel can be obtained. There was a decrease of $25 \%$ in the gas velocity $\left(u_{G}\right)$, $40 \%$ and $56 \%$ decreases in the flow rates of oils $\mathrm{A}$ and $\mathrm{B}\left(\mathrm{F}_{\mathrm{A}}\right.$ and $\left.\mathrm{F}_{\mathrm{B}}\right)$, respectively, a $200 \%$ increase in the oil $\mathrm{C}$ flow rate $\left(\mathrm{F}_{\mathrm{C}}\right)$, a $7 \%$ increase in the inlet temperature $\left(\mathrm{T}_{\mathrm{o}}\right)$, increase of $13.3 \%$ in the value of the objective function, and obtaining the product with concentration of organic sulfur compounds within the specification (Table 3). The increase in the temperature causes a higher reaction rate, and since the feasible region encomnasses a range of possible gas velocity values, the $\mathrm{u}_{\mathrm{G}}$ value has been decreased because although higher values favor the reaction, this would cause higher values of the objective function. In this way, the optimization problem is a good tool to adjust the best values of the variables of optimization in order to minimize the operational costs. The flow rates of oils A and B decreased, while the flow rate of oil C increased. As the concentrations of organic sulfur in the oils A and B (400 ppm and $300 \mathrm{ppm}$, respectively) are higher than oil C (200 ppm), the flow rates of these oils tend to decrease in the optimization problem. The $\mathrm{F}_{\mathrm{B}}$, despite having a lower concentration, decreases more than $\mathrm{F}_{A}$, since the original $\mathrm{F}_{\mathrm{B}}$ was higher than $F_{A}$. These effects occur to adjust the concentration of organic sulfur at the reactor inlet with the blending of oils $\mathrm{A}, \mathrm{B}$ and $\mathrm{C}$ in the mixer.

Simulations of the optimization problem showed that the decrease in the objective function competes with the constraint of the product at the exit of the reactor, which must have a concentration of at most 10 $\mathrm{ppm}$ in the content of organic sulfur compounds.

Process optimization that seeks to minimize the value of the operating cost and meets the product specification is necessary and of great interest. In a possible increase of scale, the costs can be high, and decreases in these costs are appreciated. The mathematical approach discussed in this paper can be used to scale up the HDS process of diesel, due to the fact that the large-scale operation has to consider, in addition to mass balance, the energy balance that considers temperature profiles within the reactor (Mederos and Ancheyta, 2007; Jarullah et al., 2011b). The optimization problem can be used to adjust the kinetic parameters of possible scale up of the reactor in the HDS process of the diesel, in order to have satisfactory answers with larger dimensions of the reactor. The optimization strategies implemented and approached from the HDS process of diesel are fundamental to estimate the operational costs of increasing the scale of production and may reduce possible problems.

Due to changes in feedstock and operating conditions to achieve ultralow sulfur diesel, existing hydrodesulfurization plants have started revamping and need to overcome many challenges such as control and operational safety (Ancheyta et al., 2002). Unknown kinetic parameters can be determined depending on the experimental information. The predicted values from the model employed should match with the experimental data as closely as possible so that errors between experimental and theoretical data are minimized (Reséndiz et al., 2007). Some authors use their experimental information to calculate kinetic parameters of hydrodesulfurization of feedstocks, and others prefer to assume the value of the parameters (Ancheyta et al., 2002). Knowing about kinetic parameters of hydrodesulfurization of feedstocks is required, and the optimization results will be influenced, impacting the products.

\section{CONCLUSIONS}

A trickle-bed reactor model was employed in this work to predict the behavior of a pilot hydrotreating reactor and to implement optimization, and the following conclusions can be pointed out:

- The blend of oils with specific characteristics in the system feed, seeking to meet the product specification is an appreciable alternative to reduce process difficulties. Thus, the blends combined to the possibility of variations in their flow rates and adjustment of the organic sulfur concentration at the TBR inlet can be used as a tool to optimize the diesel hydrotreatment process.

- The temperature and the hydrogen flowrate at the inlet of the reactor showed the highest sensitivities in the search for the oil quality at the exit of the reactor, being important variables in the adjustment to obtain the product within the specifications.

- The optimization strategy addressed can be useful in the scale up of the diesel HDT process, and the production of Ultra Low Sulfur Diesel (ULSD) can 
benefit from this methodology, seeking to obtain diesel fuel that complies with restrictive environmental laws.

\section{NOMENCLATURE}

$\Delta_{\rho \mathrm{P}} \quad$ Pressure dependence of liquid density (g $\mathrm{cm}^{-3}$ )

$\Delta_{\rho \mathrm{T}} \quad$ Temperature correction of liquid density ( $\mathrm{g}$ $\mathrm{cm}^{-3}$ )

$a_{\mathrm{L}} \quad$ Specific surface area at the liquid interface $\left(\mathrm{cm}^{-1}\right)$

as Specific surface area at the solid interface $\left(\mathrm{cm}^{-1}\right)$

$\mathrm{C}_{\mathrm{PL}} \quad$ Specific heat capacity of the liquid phase (J $\mathrm{g}^{-1} \mathrm{~K}^{-1}$ )

$\mathrm{d}_{15.6} \quad$ Specific gravity at $15.6^{\circ} \mathrm{C}$

$D_{i}^{L} \quad$ Molecular diffusivity of compound $i$ in theliquid phase $\left(\mathrm{cm}^{-2} \mathrm{~s}^{-1}\right)$

$E_{a} \quad$ Activation energy $\left(\mathrm{J} \mathrm{mol}^{-1}\right)$

$\mathrm{G}_{\mathrm{L}} \quad$ Liquid superficial mass velocity $\left(\mathrm{g} \mathrm{cm}^{-2} \mathrm{~s}^{-1}\right)$

$\mathcal{H}_{\mathrm{i}} \quad$ Henry's law constant for compound i (MPa $\mathrm{cm}^{3} \mathrm{~mol}^{-1}$ )

$\mathrm{j}_{\mathrm{H}} \quad \mathrm{j}$ factor for heat transfer

$\mathrm{K}_{\mathrm{H}_{2} \mathrm{~S}}$ Adsorption equilibrium constant for $\mathrm{H}_{2} \mathrm{~S}$ $\left(\mathrm{cm}^{3} \mathrm{~mol}^{-1}\right)$

$\mathrm{k}_{0}$ and Frequency factors

$\mathrm{k}_{0, \mathrm{H}_{2} \mathrm{~S}}$

$\mathrm{k}_{\mathrm{i}}^{\mathrm{L}} \quad$ Mass-transfer coefficient of compound $\mathrm{i}$ at the liquid interface $\left(\mathrm{cm} \mathrm{s}^{-1}\right)$

$\mathrm{k}_{\mathrm{i}}^{\mathrm{S}} \quad$ Mass-transfer coefficient of compound $\mathrm{i}$ at the solid interface $\left(\mathrm{cm} \mathrm{s}^{-1}\right)$

$\mathrm{k}_{\mathrm{L}} \quad$ Thermal conductivity of the liquid phase ( $\mathrm{J}$ $\left.\mathrm{s}^{-1} \mathrm{~cm}^{-1} \mathrm{~K}^{-1}\right)$

$\mathrm{T}_{\mathrm{L}}$ and Temperatures of liquid and solid phases (K)

$T_{S}$

$\mathrm{T}_{\text {MABP }} \quad$ Mean average boiling temperature (K)

$\mathrm{u}_{\mathrm{L}} \quad$ Superficial velocity of the liquid phase $(\mathrm{cm}$ $\left.\mathrm{s}^{-1}\right)$

$v_{c}^{\operatorname{mix}} \quad$ Critical specific volume of the liquid mixture $\left(\mathrm{cm}^{3} \mathrm{~mol}^{-1}\right)$

$v_{i, c} \quad$ Critical specific volume of the gaseous compounds i $\left(\mathrm{cm}^{3} \mathrm{~mol}^{-1}\right)$

$\mathrm{v}_{\mathrm{i}} \quad$ Molar volume of solute $\mathrm{i}$ at its normal boiling temperature $\left(\mathrm{cm}^{3} \mathrm{~mol}^{-1}\right)$

$\mathrm{v}_{\mathrm{L}} \quad$ Molar volume of solvent liquid at its normal boiling temperature $\left(\mathrm{cm}^{3} \mathrm{~mol}^{-1}\right)$

$\mathrm{v}_{\mathrm{N}} \quad$ Molar gas volume at standard conditions $\left(\mathrm{NL} \mathrm{mol}{ }^{-1}\right)$

$\Delta \mathrm{H}_{\text {ads }} \quad$ Adsorption enthalpy of $\mathrm{H}_{2} \mathrm{~S}\left(\mathrm{~J} \mathrm{~mol}^{-1}\right)$

$\Delta \mathrm{H}_{\mathrm{HDS}}$ Heat of hydrodesulfurization reaction ( $\mathrm{J}$ $\mathrm{mol}^{-1}$ )

$\lambda_{\mathrm{H}_{2}} \quad$ Solubility coefficient of hydrogen ( $\mathrm{NL} \mathrm{kg}^{-1}$ $\mathrm{MPa}^{-1}$ )
$\lambda_{\mathrm{H}_{2} \mathrm{~S}} \quad$ Solubility coefficient of hydrogen sulfide (NL kg-1 $\mathrm{MPa}^{-1}$ )

$\mu_{\mathrm{L}} \quad$ Absolute viscosity of the liquid (mPa s)

$\rho_{0} \quad$ Liquid density at standard conditions $\left(\mathrm{g} \mathrm{cm}^{-3}\right)$

$\rho_{20} \quad$ Liquid density at $20^{\circ} \mathrm{C}\left(\mathrm{g} \mathrm{cm}^{-3}\right)$

$\rho_{\mathrm{L}} \quad$ Liquid density at process conditions $\left(\mathrm{g} \mathrm{cm}^{-3}\right)$

$\epsilon \quad$ Bed void fraction

dp Equivalent particle diameter (cm)

$\mathrm{h}_{\mathrm{LS}} \quad$ Heat-transfer coefficient for the liquid film surrounding the catalyst particle $\left(\mathrm{J} \mathrm{s}^{-1} \mathrm{~cm}^{-2}\right.$ $\mathrm{K}^{-1}$ )

$\mathrm{P} \quad$ Reactor total pressure (MPa)

$\mathrm{R} \quad$ Universal gas constant $\left(\mathrm{J} \mathrm{mol}^{-1} \mathrm{~K}^{-1}\right)$

\section{REFERENCES}

Adetola, V.; and Guay, M., Integration of real-time optimization and model predictive control. Journal of Process Control, 20(2), 125-133 (2010). http:// doi.org/10.1016/j.jprocont.2009.09.001

Ahmad, M. I.; Zhang, N.; and Jobson, M., Integrated design of diesel hydrotreating processes. Chemical Engineering Research and Design, 89(7), 1025-1036 (2011). http://doi.org/10.1016/j. cherd.2010.11.021

Ali, S.A. Development of improved catalysts for deep HDS of diesel fuels. Appl Petrochem Res 4, 409-415 (2014). https://doi.org/10.1007/s13203014-0082-X

Al-Daous, M. A., and Ali, S. A., Deep desulfurization of gas oil over NiMo catalysts supported on alumina-zirconia composites. Fuel, 97, 662-669 (2012). https://doi.org/10.1016/j.fuel.2012.02.041

Alvarez, A.; Ancheyta, J.; Centeno, G.; and Marroquín, G., A modeling study of the effect of reactor configuration on the cycle length of heavy oil fixedbed hydroprocessing. Fuel, 90(12), 3551-3560 (2011). https://doi.org/10.1016/j.fuel.2011.03.043

Alvarez, A.; and Ancheyta, J., Simulation and analysis of different quenching alternatives for an industrial vacuum gasoil hydrotreater. Chemical Engineering Science, 63(3), 662-673, (2008a). https://doi.org/10.1016/j.ces.2007.10.007

Alvarez, A.; and Ancheyta, J., Modeling residue hydroprocessing in a multi-fixed-bed reactor system. Applied Catalysis A: General, 351(2), 148-158 (2008b). http://doi.org/10.1016/j. apcata.2008.09.010

Ancheyta, J.; Angeles, M. J.; Macías, M. J.; Marroquín, G.; and Morales, R., Changes in Apparent Reaction Order and Activation Energy in the Hydrodesulfurization of Real Feedstocks. Energy \& Fuels, 16, 189-193 (2002). http://doi. org/10.1021/ef0101917 
Ancheyta, J.; Rana, M. S.; and Furimsky, E., Hydroprocessing of heavy petroleum feeds: Tutorial. Catalysis Today, 109(1-4), 3-15 (2005). http://doi. org/10.1016/j.cattod.2005.08.025

Ani, A. B.; Ebrahim, H. A.; and Azarhoosh, M. J., Simulation and Multi-Objective Optimization of a Trickle-Bed Reactor for Diesel Hydrotreating by a Heterogeneous Model Using Non-Dominated Sorting Genetic Algorithm II. Energy and Fuels, 29, 30413051 (2015).

ANP - Agência Nacional do Petróleo, Gás Natural e Biocombustíveis. Sistema de Levantamento de Preços (2017). Available in < http://www.anp.gov.br/preco/ >

Aye, M. M. S.; and Zhang, N., A novel methodology in transforming bulk properties of refining streams into molecular information. Chem. Eng. Science, 60, 6702-6717 (2005).

Bao, H.; Fang, X.; Liu, J.; and Song, Y., Advance in kinetics model of diesel hydrodearomatization reaction. Liaoning, China: Chemical Industry and Engineering Progress, 30(5), 1000-6613 (2011).

Bhaskar, M.; Valavarasu, G.; Sairam, B.; Balaraman, K. S.; and Balu, K., Three-Phase Reactor Model to Simulate the Performance of Pilot-Plant and Industrial TrickleBed Reactors Sustaining Hydrotreating Reactions. Industrial \& Engineering Chemistry Research, 43(21), 6654-6669 (2004). http://doi.org/10.1021/ie049642b

Cooper, B. H.; and Donnis, B. B. L., Aromatic saturation of distillates: an overview. Applied Catalysis A: General, 137, 203-223 (1996).

Danckwerts, P. V., Continuous flow systems. Distribution of residence times. Chemical Engineering Science, 50(24), 3857-3866 (1995). https://doi. org/10.1016/0009-2509(96)81811-2

Ferreira, A. S.; Nicoletti, M. C.; Bertini, J. R.; and Giordano, R. C., Methodology for inferring kinetic parameters of diesel oil HDS reactions based on scarce experimental data. Computers and Chemical Engineering, 48, 58-73(2013). http://doi.org/10.1021/ acs.energyfuels. 5 b00467

Hindmarsh, A. C.; Brown, P. N.; Grant, K. E.; Lee, S. L.; Serban, R.; Shumaker, D. E.; and Woodward, C. S. SUNDIALS, suite of nonlinear and differential/ algebraic equation solvers. ACM Trans. Math. Softw., 31, 363-396, 2005.

Jarullah, A. T.; Mujtaba, I. M.; and Wood, A. S., Kinetic model development and simulation of simultaneous hydrodenitrogenation and hydrodemetallization of crude oil in trickle bed reactor. Fuel, 90(6), 2165-2181 (2011a). http://doi.org/10.1016/j.fuel.2011.01.025

Jarullah, A. T.; Mujtaba, I. M.; and Wood, A. S., Modelling and Optimization of Crude Oil Hydrotreating Process in Trickle Bed Reactor: Energy Consumption and Recovery Issues. Chemical Product and Process Modeling, 6(2) ISSN (Online) 1934-2659 (2011b), https://doi. org/10.2202/1934-2659.1600
Jimenez, F.; Ojeda, K.; Sanchez, E.; Kafarov, V.; and Maciel Filho, R., Modeling of trickle bed reactor for hydrotreating of vacuum gas oils: effect of kinetic type on reactor modeling. Computer Aided Chem. Eng., 24, 515-520 (2007).

Kallinikos, L. E.; Jess, A.; and Papayannakos, N. G., Kinetic study and $\mathrm{H} 2 \mathrm{~S}$ effect on refractory DBTs desulfurization in a heavy gasoil. Journal of Catalysis, 269(1), 169-178 (2010). https://doi. org/10.1016/j.jcat.2009.11.005

Korsten, H., and Hoffmann, U., Three-Phase reactor model for hydrotreating in pilot tricke-bed reactors. AIChE Journal, 42(5), 1350-1360 (1996).

Li, D.; Li, Z.; Li, W.; Liu, Q.; Feng, Z.; and Fan, Z., Hydrotreating of low temperature coal tar to produce clean liquid fuels. Journal of Analytical and Applied Pyrolysis, 100 (2013) 245-25 (2013).

Liu, Z.; Zheng, Y.; Wang, W.; Zhang, Q.; and Jia, L., Simulation of hydrotreating of light cycle oil with a system dynamics model. Applied Catalysis A: General, 339(2), 209-220 (2008). http://doi. org/10.1016/j.apcata.2008.01.018

Mederos, F. S.; and Ancheyta, J., Mathematical modeling and simulation of hydrotreating reactors: Cocurrent versus countercurrent operations. Appl. Cat. A: General, 332(1), 8-21 (2007). http://doi. org/10.1016/j.apcata.2007.07.028

Mederos, F. S.; Ancheyta, J.; and Elizalde, I., Dynamic modeling and simulation of hydrotreating of gas oil obtained from heavy crude oil. Appl. Cat. A: General, 425-426, 13-27 (2012).

Murali, C.; Voolapalli, R. K.; Ravichander, N.; Gokak, D. T.; and Choudary, N. V., Trickle bed reactor model to simulate the performance of commercial diesel hydrotreating unit. Fuel, 86, 1176-1184 (2007).

Novaes, L. R.; Resende, N. S.; Salim, V. M. M.; and Secchi, A. R., Modeling, simulation and kinetic parameter estimation for diesel hydrotreating. Fuel, 209, 184-193 (2017). http://dx.doi.org/10.1016/j. fuel.2017.07.092

Pacheco, M. E.; Salim, V. M. M.; and Pinto, J. C., Accelerated deactivation of hydrotreating catalysts by coke deposition, Industrial and Engineering Chemistry Research, 50, 5975-5981 (2011).

Reséndiz, E.; Ancheyta, J.; Rosales-Quintero, A.; and Marroquín, G., Estimation of activation energies during hydrodesulfurization of middle distillates. Fuel, 86, 1247-1253 (2007). http://doi. org/10.1016/j.fuel.2006.09.023

Rodríguez, M. A.; and Ancheyta, J., Modeling of Hydrodesulfurization(HDS), Hydrodenitrogenation (HDN), and the Hydrogenation of Aromatics (HDA) in a Vacuum Gas Oil Hydrotreater. Energy Fuels, 2004, 18 (3), 789-794 (2004). http://doi. org/10.1021/ef030172s 
Shokri, S.; Zahedi, S.; Marvast, M. A.; Baloochi, B.; and Ganji, H., Experimental Analysis of Diesel Hydrotreating Reactor to Development a Simplified Tool for Process Real- time Optimization. World Academy of Science, Engineering and Technology, 45, 561-567 (2010).

Soares, R. P.; and Secchi, A. R., EMSO: A new environment for modelling, simulation and optimization. Computer Aided Chemical Engineering, 14, 947-952 (2003). http://doi. org/10.1016/S1570-7946(03)80239-0

Stanislaus, A.; Marafi, A.; and Rana, M. S., Recent advances in the science and technology of ultra low sulfur diesel (ULSD) production. Catalysis Today, 153(1-2), 1-68 (2010). http://doi.org/10.1016/j. cattod.2010.05.011

Tao, X.; Zhou, Y.; Wei, Q.; Ding, S.; Zhou, W.; Liu, T.; and Li, X., Inhibiting effects of nitrogen compounds on deep hydrodesulfurization of straight-run gas oil over a NiW/Al $\mathrm{O}_{2}$ catalyst. Fuel. 188, 401-407 (2017). https://doi. org/10.1016/j.fuel.2016.09.055

Wächter, A.; and Biegler, L. T., On the implementation of an interior-point filter line-search algorithm for large-scale nonlinear programming. Math. Program., Ser. A. 106, 25-57 (2006). http://doi. org/10.1007/s10107-004-0559-y

Yui, S. M.; and Sanford, E. C., Kinetics of aromatics hydrogenation of bitumen-derived gas oils. The Canadian Journal of Chemical Engineering, 69(5), 1087-1095 (1991). http://doi.org/10.1002/ cjce. 5450690507

Zhang, B. J.; Chen, Q. L.; Hu, S.; Gu, W. G.; and Hui, C. W., Simultaneous optimization of energy and materials based on heat exchanger network simulation for diesel hydrotreating units. Chemical Engineering Research and Design, 88(5-6), 513-519 (2010). http://doi.org/10.1016/j.cherd.2009.09.009

\section{APPENDIX}

Model parameters and mathematical correlations were taken from Korsten and Hoffmann (1996), Mederos and Ancheyta (2007), Jiménez et al. (2007), Liu et al. (2008), Alvarez and Ancheyta (2008a), Alvarez and Ancheyta (2008b) and Mederos et al. (2012), and are summarized in Table 4.

Table 4. Parameters and correlations used in the model.

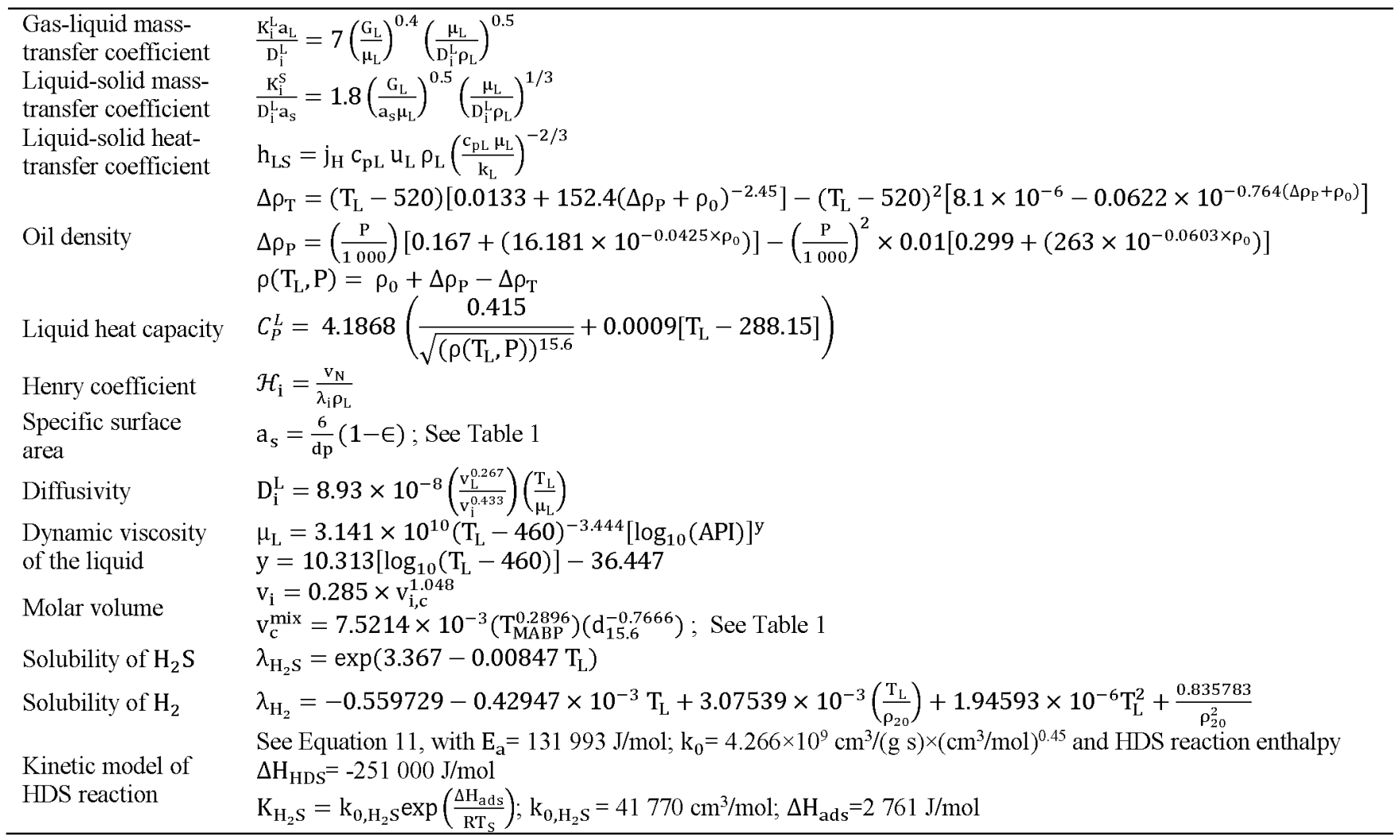

